\title{
The spectrum of employment policies and their impact on the labour market in Montenegro
}

\begin{abstract}
The negative situation on the Montenegrin labour market has improved in recent years. The labour market is affected by a wide range of government actions in the fields not only of employment policy but also of education, social welfare, business regulation, taxation, etc. Therefore, one of the goals in implementing labour legislation is to ensure that impacts on employment are fully taken into account in the formulation of policy in these other fields. Numerous policies addressing particular aspects and the better functioning of the labour market are ongoing or in preparation. However, there is still much room for improvement. Currently, the Montenegrin labour market is fragmented and segmented in terms of high regional disparities, gender inequality and a mismatch between labour supply and labour demand. Also, it should be emphasised that the number of long-term unemployed people is at a relatively high level. This suggests that further efforts should be made at all levels in order to overcome such a situation.
\end{abstract}

Keywords: labour market, transition, crisis, activity rate, unemployment, youth unemployment, industrial change, aging society, employment taxes, education policy, active labour market measures, public employment services, migration

\section{Labour market situation}

In 2006, Montenegro became an independent state. The post-independence period was marked by a high GDP growth rate, driven mostly by a high inflow of FDI and an increase in services sector activities such as tourism and tourism-related activities and the real-estate sector. GDP real growth rate in 2006 was at a level of $8.6 \%$, while in 2007 it reached $10.7 \%$ before falling back in 2008 to $6.9 \%$.

Positive trends in the economy have influenced the labour market in the same way since Montenegro started developing modern and sophisticated labour market programmes and institutions. In Montenegro, conditions for the movement of labour and access to the labour market have been improving. Despite the progress achieved on the Montenegrin labour market over the last several years (especially in terms of the falling unemployment rate), however, several serious deficiencies nevertheless remain.

The labour market of Montenegro has undergone large shifts during the transition, but structural problems have remained, such as high inactivity rates, low levels of female labour market participation, a high incidence of long-term unemployment, a mismatch between labour supply and labour demand, territorial imbalances and slow increases in productivity. All of these could be attributed to several factors - job losses due to restructuring, entry barriers to the labour market, etc. Also, the impacts of the 
global economic crisis are spilling over into Montenegro. Consequently, this is having a negative effect on labour market developments.

\section{Employment rates}

In the few past years, the employment rate in Montenegro has grown at a fast pace. According to the Labour Force Survey, the highest employment rate was recorded in $2008(43.2 \%)$ and the lowest in 2006 (34.5\%). In 2010, it stood at $40.3 \%$, while the Survey which was conducted in the second quarter of 2011 showed the employment rate continuing a decreasing trend, amounting to $39.6 \%$.

Figure 1 - Employment rate in Montenegro

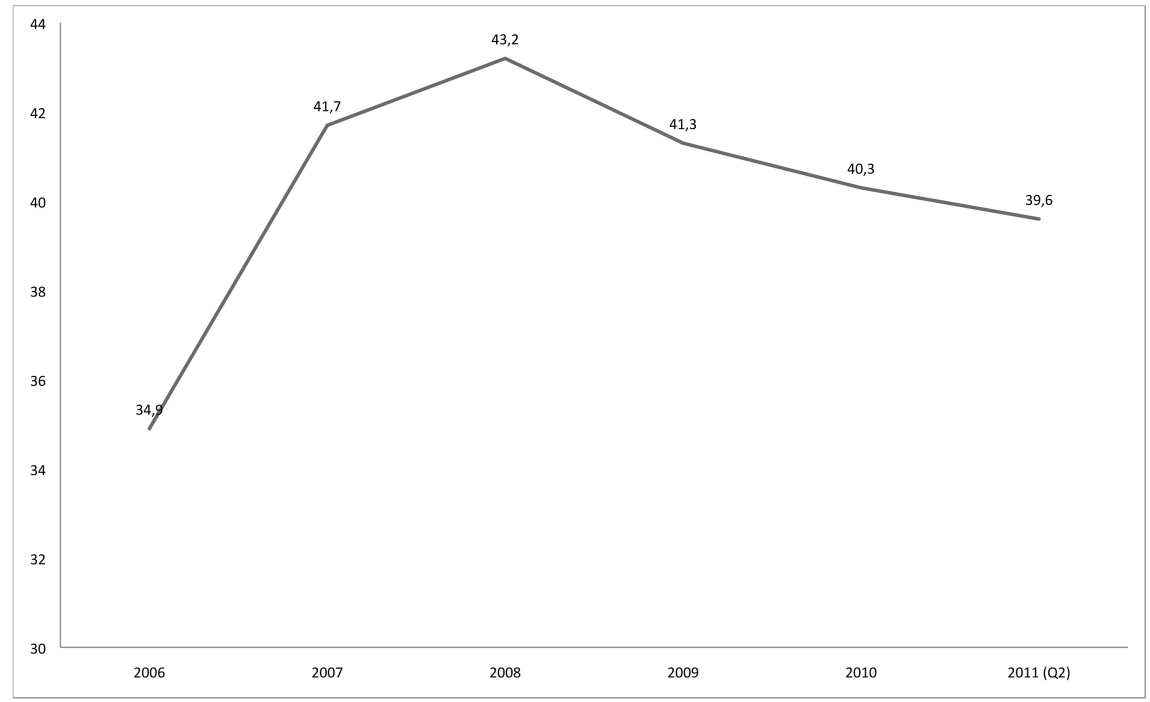

The employment to population ratio is lower in Montenegro than in most other economies, in which it has a value of between $50 \%$ and $70 \%$. In Montenegro, with the employment rate for people aged 15 and above being at a level of $39.6 \%,{ }^{1}$ and $46.6 \%$ for the population of working age (15-64), this ratio is somewhat lower than the usual, but it is not considered low. This indicator provides information on the ability of an economy to create jobs and it is considerably impaired if its value is below $35 \%$.

Employment rates are not equal regarding gender. The employment rate for women is lower than the average employment rate. In 2010, the female employment rate stood at $33.8 \%$, while the total employment rate stood at $41.3 \%$. Despite a slight increase in the female employment rate, it is still much lower than the male employment rate, which amounted to $47.1 \%$ in 2010. A similar situation was registered in 2011 (Q2) when the female employment rate amounted to $33.0 \%$ in comparison to a male rate of $46.6 \%$.

1 Most recent available data (the second quarter of 2011). 


\section{Unemployment rates}

In Montenegro, data on unemployment are subject to the different methodologies employed by MONSTAT and the Employment Agency of Montenegro (EAM). MONSTAT uses ILO methodology, while the EAM takes into account unemployed people registered with the Agency.

According to the EAM, the unemployment rate (unemployed people who are registered with the EAM as a percentage of the total number of the active population $(15+)$ ) has been constantly and quite rapidly decreasing: from its peak, $32.8 \%$ in 2000 , to $10.6 \%$ in 2008. After 2008, however, the unemployment rate increased as a consequence of the crisis. The unemployment rate started to increase during the second part of 2009, for the first time in eight years.

According to MONSTAT, the unemployment rate was $29.6 \%$ in 2006 where after it decreased, reaching a low in 2008. In 2009, it rose and then stayed around that level during 2010 and in the first half of 2011.

Table 1 - Unemployment rate in Montenegro, 2006-2011 (Q2)

\begin{tabular}{|l|c|c|c|c|c|c|}
\hline & $\mathbf{2 0 0 6}$ & $\mathbf{2 0 0 7}$ & $\mathbf{2 0 0 8}$ & $\mathbf{2 0 0 9}$ & $\mathbf{2 0 1 0}$ & $\mathbf{2 0 1 1}$ (Q2) \\
\hline EAM & 15.4 & 11.9 & 10.6 & 10.7 & 12.1 & 11.2 \\
\hline MONSTAT (LFS) & 29.6 & 19.4 & 16.8 & 19.1 & 18.9 & 19.1 \\
\hline
\end{tabular}

Source: MONSTAT, EAM

Despite MONSTAT and the EAM using different methodologies regarding the calculation of the unemployment rate in Montenegro, the trends in unemployment rates are the same.

Even though it has been falling in recent years, there remains a substantial gender gap with respect to unemployment in Montenegro. Overall, the difference in unemployment rate between the genders is also partly a consequence of the lower activity rates among women (43\% among females and $59 \%$ among males).

Table 2 - Unemployment rates by gender, 2006-2011

\begin{tabular}{|l|c|c|c|c|c|c|}
\hline & $\mathbf{2 0 0 6}$ & $\mathbf{2 0 0 7}$ & $\mathbf{2 0 0 8}$ & $\mathbf{2 0 0 9}$ & $\mathbf{2 0 1 0}$ & $\begin{array}{c}\mathbf{2 0 1 1} \\
\text { (Q2) }\end{array}$ \\
\hline Unemployed women & 33582 & 24000 & 20800 & 23500 & 22700 & 22500 \\
\hline Female unemployment rate & 30.1 & 20.9 & 17.9 & 20.4 & 20.6 & 21.0 \\
\hline Unemployed men & 41238 & 27000 & 24000 & 26900 & 27300 & 26900 \\
\hline Male unemployment rate & 29.1 & 18.1 & 15.9 & 18.0 & 18.9 & 19.1 \\
\hline
\end{tabular}

Source: MONSTAT, Labour Force Survey 2006-2011(Q2) 


\section{Sectoral changes}

The sectoral changes in Montenegro during recent years are similar to those in other countries in transition, since the main change has been the movement towards a service economy. Subsequent to the beginning of transition, the agricultural and industrial sectors have been declining, to the advantage of the service sector. Major industries that have seen a reduction in the workforce include agriculture (from $3.3 \%$ in 2001 to $1.7 \%$ in 2008 ; $^{2}$ transport, storage and communications (from $10.1 \%$ in 2001 to $8.4 \%$ in 2010 and $7.5 \%$ in Q2 of 2011); and education (from $11.5 \%$ in 2001 to $6.3 \%$ in 2010 and $6.0 \%$ in the second quarter of 2011). Concerning the mining and manufacturing sector, its share in total employment has decreased from $27 \%$ in 2001 to $11.2 \%$ in 2010 and $8.6 \%$ in Q2 of 2011 . The public administration sector alone employs $9.5 \%$ of the employed workforce, which is higher than the mining and manufacturing sector during the second quarter of 2011.

Conversely, employment in the services sector had a share of $60 \%$ in 2001 and this increased to $73.9 \%$ in 2010 and to $75.4 \%$ in 2011 Q2. This growth of employment in services is mainly a result of the development of tourism. Bearing in mind that Montenegro has become a very attractive tourist destination, the number of employees in hotels and restaurants has been growing over the last decade. In 2001, the share of employees in this sector in total employment was $5.7 \%$, but by 2010 this had climbed to $8.5 \%$. A similar improvement is recorded in the real estate sector, which took a share of just $1 \%$ in 2001 ; in 2010, it stood at $3.7 \%$ (there are as yet no data for 2011). Additionally, the expansion of the financial sector has created jobs in the financial intermediation industry. Also, Montenegro is the country with the highest level of employment in wholesale and retail trade. In 2001, the share of this sector in total employment was $8.9 \%$, but at the end of 2010 it had increased to $22.5 \%(21.7 \%$ in 2011 Q2).

According to this explanation, it is obvious that the services sector is dominant, with a share of total employment which has increased over time. In 2010, less than onethird (around $26 \%$ ) of those employed were working outside the service sector (agriculture: $6.2 \%$; industry: $20 \%$ ), leaving the vast majority $(73.8 \%)$ of the employed population in the services sector.

Geographically, the largest part of agricultural activity (48\%) is concentrated in the north, whereas $90 \%$ of all employment in the coastal region is in services.

Besides the changes in employment by sector, the employment structure has also changed in terms of ownership. The share of people employed in the public sector amounted to $60 \%$ in 2000 , but this had reduced, as a result of the privatisation process, to $42.7 \%$ by the second quarter of 2011 . At the same time, thanks to the decline in employment in socially-owned enterprises, employment in the private sector, as a percentage of total employment, has been rising, from $41 \%$ in 2000 to $57.3 \%$ in 2011 Q2.

2 According to the LFS, there was an important increase with respect to the share of employment in agricultural activities in overall employment in 2009 and 2010 compared with the previous period. Namely, in 2009 the share of employment in agricultural activities reached $6.5 \%$ while in 2010 it amounted to $6.2 \%$. 
Figure 2 - Share of total employment by industrial sector (2010)

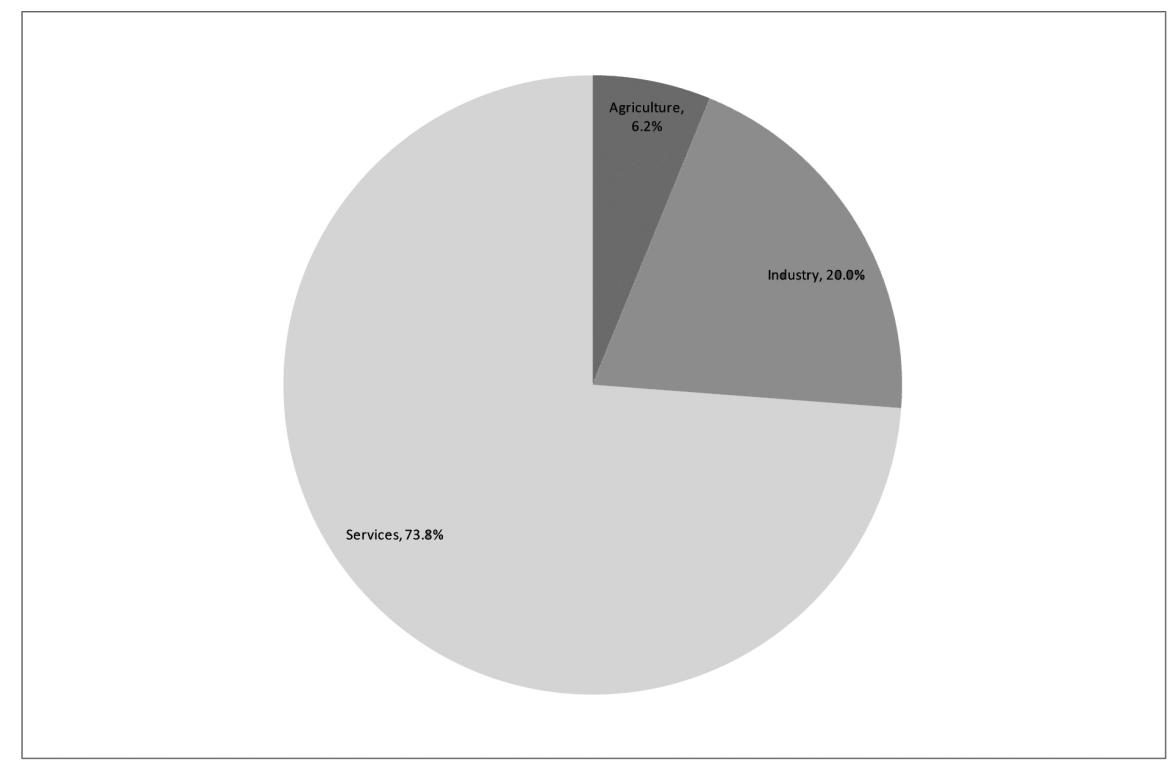

\section{Adjustment patterns}

The global crisis has affected the labour market as well and there have been necessary adjustments to the new situation. A slowdown in economic activity was noticed in the last quarter of 2008 while in 2009 GDP decreased by $5.7 \%$. The most significant decrease was recorded in the following sectors: industry $(-32.2 \%)$; construction $(-21.8 \%)$; and trade $(-8.9 \%)$. The decrease in these sectors was partially covered by tourism revenues that were sustained at the level of the previous year, as well as the activation of agricultural resources and production, and an increase in FDI which, in 2009 , was at a record level of about $€ 1 \mathrm{bn}$.

This situation required certain adjustments to policies. Fiscal policy was focused on fiscal adjustment to the crises, which resulted in a budget deficit of $2.3 \%$ of GDP. The decrease in budget revenues was partly caused by lower collection of taxes and contributions. Budget expenditure in 2009 was $7.13 \%$ lower than planned expenditure. The highest share of total expenditure (around $30 \%$ ) was accounted for by social protection transfers, which recorded an increase of more than $11 \%$ compared with 2008. However, the highest increase (of almost $170 \%$ ) was recorded in subsidies, which is a direct consequence of the provision of state support in order to overcome the consequences of the economic crisis.

However, the formal labour market, which had recorded a positive trend prior to the crisis, did not suffer seriously in terms either of overall employment (which registered growth prior to the crisis) or unemployment (which registered decline prior to the 
crisis): both remained at a similar level during the early stages of the crisis. In February 2009, the Montenegrin government decided to stop employment in the public sector in order to contribute to the envisaged level of budget saving during the crisis. This decision was made in early 2009, but its effects were not evident during 2010 since employment in the public sector remained almost the same.

Despite the positive trends in registered employment, there was a disturbing trend in registered unemployment, since the amount of compensation for the unemployed, to which all those who have at least six months' work experience are entitled, increased during 2009. Based on EAM data, the average number of people receiving unemployment benefit amounted to around 9500 , while in 2009 it increased to 12500 , representing an increase of more than $30 \%$. During 2010, it remained at the same level.

Negative effects of the crises were noticed on the Montenegrin labour market in the second half of 2009, and they became more visible during the last quarter of that year and during 2010. In 2009, industrial sub-sectors such as the Aluminium Plant (KAP), the Steel Factory, Bauxite Mine Nikšić, and Coal Mine Pljevlja, as a consequence of restructuring, started to record a decreasing number of employees, a process which continued during 2010. The total number of employed people in these companies amounted to 1288 (KAP), 1460 (Steel Factory Nikšić), 530 (Bauxite Mine Nikšić) and 1500 (Coal Mine Pljevlja) while the number of workers that were laid off amounted to, respectively, 524; $400 ; 300$; and 370 . However, there are no exact data on the realisation of such plans.

The overall unemployment rate increased to $12.1 \%$ in 2010 (according to the EAM), while the change in employment in the first two quarters of 2011 followed the changes in economic activity: there was a noticeable decrease in employment in the industrial sector, while employment in agriculture increased. Bearing in mind the number of people that are planned to be laid off in the future, it can be expected that the number of recipients of unemployment benefits will be at a higher level during 2011. This will present a significant additional burden to the Montenegrin budget, which is already in deficit.

The recommendations of the International Labour Organisation (ILO) for a national policy to reduce unemployment as well as the impact of the global economic crisis on unemployment could be summarised as follows:

- an appropriate mix of active and passive labour market policies

- adjustment of the transfers made for social security and pensions in order to avoid their devaluation

- support for enterprises, especially SMEs, in overcoming problems with liquidity and in securing loans

- public investment in infrastructure

- support and help for vulnerable groups

- restructuring of companies in a socially-responsible manner

- strengthening of institutions that provide services for the unemployed

- incentives and investment in energy-efficient technologies and 'green jobs'

- development of the social dialogue.

If we consider the recommendations of the ILO, it could be concluded that their implementation has already started in Montenegro. Namely, during the last couple of 
years, the level of taxes and contributions has declined. In 2009, the total amount of taxes and contributions represented $63 \%$ of the net wage, which makes Montenegro more business-friendly and removes the barrier which forced most employers in Montenegro to report a minimal wage in order to pay minimal taxes and contributions.

However, the level of contributions as a percentage of the gross wage increased during 2010 in order to maintain the revenues of the Pension Fund and the Health Insurance Fund at a sustainable level as well as to reduce the amount of transfers to these funds from the state budget, which has already entered the area of deficit.

In addition, the problems in manufacturing industry need to be resolved by restructuring and supporting the major companies in the sector. Also, the government of Montenegro is trying to invest in infrastructure and stimulate employment. For example, the government is in a process of negotiation regarding the building of a motorway through Montenegro. The start of the construction of the motorway would represent a major incentive for the Montenegrin labour market because of the estimate that one to two thousand workers, with various skills levels would be employed on such a project.

Regarding 'green jobs', the projects of encouraging and financing energy efficiency programmes are already in the implementation phase. There is an encouraging attitude towards the increasing importance of green technology. The Centre for Vocational Education has already established several educational programmes supporting energy matters. These have delivered the levels of knowledge applicable to new sources of energy as a result of the representatives of this institution emphasising the increasing demand for occupations in the area of high voltage electricity and new sources of energy.

During the times of crisis, Montenegro has managed to improve the balance between labour market needs and the education system. However, there is much room for further improvement in this area, since the current education system still does not completely match the needs of the labour market and certain skills profiles are still deficient on the market. There is evidence that tourism and the construction industry are sectors that have suffered the most from the lack of supply of a skilled labour force, even during the crisis, because there was a large number of foreign workers in these sectors in previous years. Also, agriculture, as well as the wood processing sector, are recognised by the EAM as sectors with a lack of certain skill profiles. Therefore, the EAM plans to begin the implementation of special programmes in order to improve the supply of the labour force to the Montenegrin labour market. Programmes have also been created in order to stimulate employment in the northern region, while special incentive measures have been designed for the employment of people who cannot easily find a job.

Despite the efforts to neutralise the impact of the crisis on the labour market, local level measures cannot solve all the problems. Therefore, the recovery of the economy, i.e. the continuation of growth trends, and consequently the development of the labour market, will partially depend on the resolution of the problems at a global level. Developments in the future will largely depend on developments in the global economy, which will have an impact on the position of the economy of Montenegro (the tourist season; a way to resolve the crisis in manufacturing industry; privatisation in the energy sector; etc.). The resolution of problems related to the liquidity of Montenegrin companies, the finalisation of the restructuring of a number of large economic systems, 
maintenance of budget policy in accordance with economic reality, the stabilisation of the banking system and the further attraction of foreign direct investment should significantly define the trends on the labour market.

\section{Gender topics}

Over recent years there have also been noticeable changes with respect to the structure of employment by gender. Out of the total number of employees, on average $58 \%$ are men and $42 \%$ are women. Over the last six years, the rate of growth in women's participation in overall employment has been $1.3 \%$ per year, but their share of overall employment remains lower than that of men. Despite having a similar level of education, women have lower participation in overall employment compared to men. This is partly due to women being in a poorer position to start their own business since they lack enough collateral (land, real estate, etc.) in order to obtain bank loans due to the custom in Montenegro according to which all family inheritance goes to male children.

Table 3 - Number of employees by gender, 2006-2011 (Q2)

\begin{tabular}{|l|c|c|c|c|c|c|}
\hline & $\mathbf{2 0 0 6}$ & $\mathbf{2 0 0 7}$ & $\mathbf{2 0 0 8}$ & $\mathbf{2 0 0 9}$ & $\mathbf{2 0 1 0}$ & $\mathbf{2 0 1 1}(\mathbf{Q 2})$ \\
\hline Total & 178364 & 212700 & 221900 & 213600 & 202300 & 198600 \\
\hline Male & 100250 & 121700 & 126800 & 122200 & 116200 & 113800 \\
\hline Female & 78113 & 91000 & 95100 & 91400 & 86100 & 84800 \\
\hline
\end{tabular}

Source: LFS, MONSTAT

Regarding employment rates by gender, it is noticeable that employment rates are unequal and a gender gap in employment exists. The employment rate by gender follows the same pattern as the total employment rate, as well as the activity rate, since the female employment rate is lower than the average employment rate. In 2010, the employment rate for women amounted to $33.8 \%$ while the total employment rate stood at $40.3 \%$. In spite of experiencing growth over the observed period (e.g. the employment rate for women in 2005 was just $27.6 \%$ ), the female employment rate remains much lower than the male employment rate, which has also grown in this same period, from $42.4 \%$ in 2005 to $47.1 \%$ in 2010 .

Unemployment among both men and women has been decreasing since 2000 . However, the conclusion is that, for both genders, the risk of being unemployed decreases with age. In 2007 there was, compared with previous years, an important reduction in the number of both unemployed women and men, although the trend was more pronounced with respect to men. Additionally, there was a trend towards a reduction in women's share of total unemployment, which can be explained by new jobs being opened in some sectors which employ mainly women (trade, tourism, etc.). This is additionally supported by women being more present on training programmes organised by the EAM, all with a view to gaining new skills and knowledge that might assist them find a job. 
According to both EAM and MONSTAT, there have constantly been more men unemployed (in absolute terms) than women since 2005. However, the unemployment rate is higher among women, according to the MONSTAT data, which may suggest that women are more likely to register as unemployed in order to gain health insurance.

The difference in the unemployment rate between the sexes is also partly caused by lower activity rates among women $(42.6 \%$ among women and $58.1 \%$ among men in 2010). This indicates that there is still a gender gap with respect to unemployment in Montenegro.

The effects of the crisis on the labour market became more visible in the last quarter of 2009 , when the unemployment rate for men amounted to $19.2 \%$, or 4.2 percentage points higher than in the same period of 2008. The unemployment rate among women in the fourth quarter of 2009 amounted to $21.8 \%$, which represents an increase of 3.6 percentage points in comparison with the same period of 2008. Similar trends continued in 2010 when, according to the LFS, women made up $45.3 \%$ of the total number of the unemployed, while the unemployment rate for the female and male population amounted to $20.6 \%$ and $18.9 \%$, respectively. During the first two quarters of 2011, the unemployment rates amounted to $21 \%$ for women and $19.1 \%$ for men.

\section{Demographic topics}

The results of the Census of 2011 show that the total population of Montenegro has slightly decreased since the 2003 Census. In 2003 and 2011, the total population was 620145 and 620029 , respectively. More concerning is the presence of an aging population: a problem that Montenegro has faced during previous decades. The share of the elderly in the total population has significantly increased: the number of people aged 65 or older amounted to 50603 in 1991, while it increased to 85535 in 2011, at an average annual growth rate of $2.66 \%$. At the same time, the share of the young population (in the 0-14 age group) registered an average annual decrease of $1.53 \%$ (from 155458 in 1991 to 116453 in 2011). This is a consequence of low fertility rates. The working age population (aged 15-64) registered a slight increase, but the expectation is that the number of people who belong to this age group will also reduce in the future as a result of the current low fertility rates.

In addition, women accounted for around $51 \%$ of the total population in 2011; a percentage that has not changed significantly since the last Census.

With the small overall increase between 2003 and 2011, the share of the 15-64 age group (the base of the economically active population) in the total Montenegrin population is almost the same every year, i.e. around $67 \%$. The growth trend is the highest amongst the population aged between 45 and 54 . There is a decrease in the youngest age group, aged from 15 to 24, throughout the period; probably as a result of decreased fertility. In addition to this, the sharpest decrease in the observed period is recorded among the 25-34 age group. Finally, the 35-44 age group recorded a certain constant increase. All these demographic patterns lead to the conclusion that Montenegro is a country with an aging population. 
Table 4 - The age structure of the population in Montenegro

\begin{tabular}{|c|c|c|c|c|c|c|c|}
\hline $\begin{array}{l}\text { Census } \\
\text { Year }\end{array}$ & 1953 & 1961 & 1971 & 1981 & 1991 & 2003 & 2011 \\
\hline $\begin{array}{l}\text { Age } \\
\text { group }\end{array}$ & \multicolumn{7}{|c|}{ Number of citizens } \\
\hline Total & 419855 & 471612 & 526937 & 581972 & 608815 & 628295 & 620029 \\
\hline $0-14$ & 149144 & 171658 & 169139 & 160546 & 155458 & 131883 & 116453 \\
\hline $15-64$ & 239781 & 266514 & 317417 & 373406 & 402754 & 421256 & 422041 \\
\hline $65+$ & 30930 & 33440 & 40417 & 48020 & 50603 & 75156 & 81535 \\
\hline $80+$ & 5972 & 7088 & 8322 & 9366 & 11215 & 10087 & 15530 \\
\hline $\begin{array}{l}\text { Age } \\
\text { group }\end{array}$ & \multicolumn{7}{|c|}{ Share of the population (\%) } \\
\hline $0-14$ & 35.5 & 36.4 & 32.1 & 27.6 & 25.5 & 21.0 & 18.78 \\
\hline $15-64$ & 57.1 & 56.5 & 60.2 & 64.2 & 66.2 & 67.0 & 68.07 \\
\hline $65+$ & 7.4 & 7.1 & 7.7 & 8.3 & 8.3 & 12.0 & 13.15 \\
\hline $80+$ & 1.4 & 1.5 & 1.6 & 1.6 & 1.8 & 1.6 & 2.50 \\
\hline $\begin{array}{l}\text { Aging } \\
\text { index }\end{array}$ & 21 & 19 & 24 & 30 & 33 & 57 & 70 \\
\hline
\end{tabular}

Source: MONSTAT Census data

The average age of the Montenegrin population has been increasing over the years and, in 2003 and 2011, the average age was 35.8 and 37.5 respectively. This indicator shows that the population of Montenegro is getting older from year-to-year.

Bearing in mind these movements in the Montenegrin demographic system, it is likely that demographic developments will continue to exert pressure on the labour market in the years to come as a result of the increased duration of life of Montenegrin citizens and the falling fertility rate.

3 The number of people aged 65 years old or over per hundred people below the age of 15 . 
Figure 3 - Average age of population in Montenegro

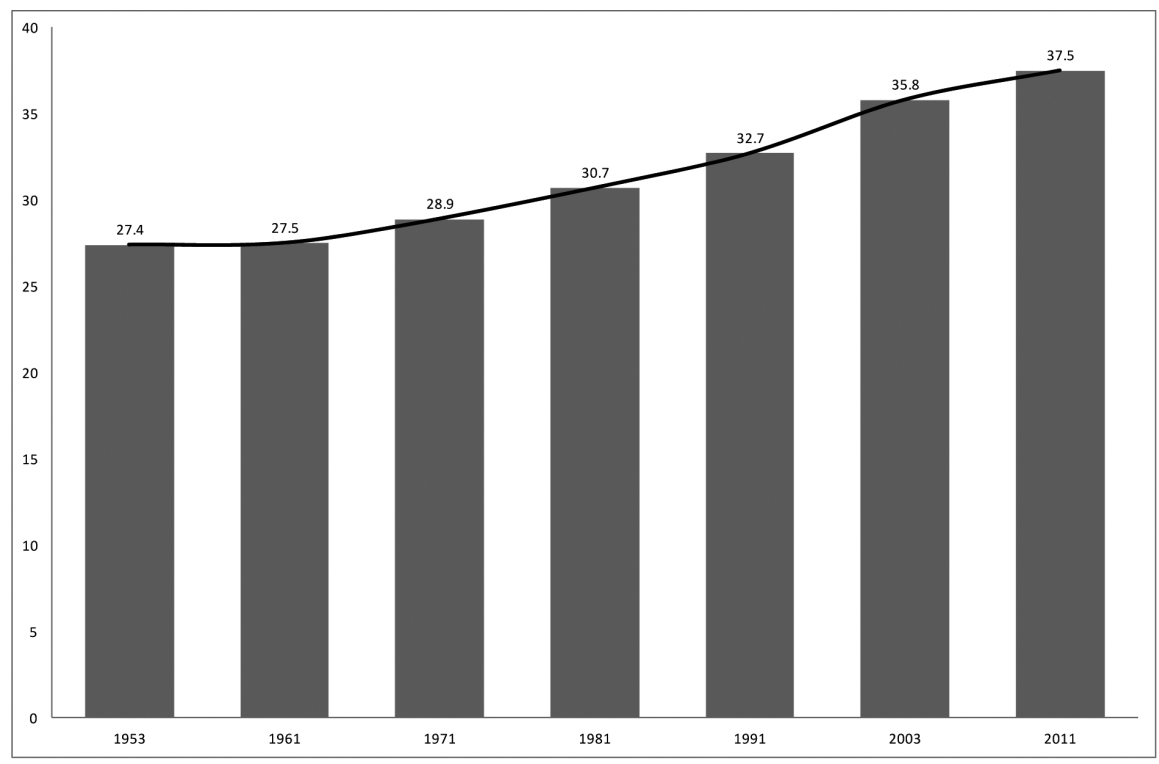

\section{Youth unemployment}

The age structure of the unemployed has also changed, but it is still unfavourable. The unemployment rate among young people (aged 15-24) was 59.5\% in 2006, although this reduced to $37.3 \%$ in Q2 of 2011 (around $57 \%$ of which were young men and $43 \%$ were young women). The problem with the youth unemployment rate is dominant in the overall unemployment structure, since young people face the highest unemployment rate of all age groups and have an unemployment rate which is significantly higher than the average. The very high unemployment rate among young people is a consequence of their inability to find a job and is not predominantly a reflection of poor education attendance. 
Table 5 - Unemployment rate by age, 2006-2011 (Q2)

\begin{tabular}{|l|c|c|c|c|c|c|c|}
\hline & $\mathbf{1 5}+$ & $\mathbf{1 5 - 2 4}$ & $\mathbf{2 5 - 3 4}$ & $\mathbf{2 5 - 5 4}$ & $\mathbf{3 5 - 5 4}$ & $\mathbf{5 5 - 6 4}$ & $\mathbf{1 5 - 6 4}$ \\
\hline 2006 & 29.6 & 59.5 & 35.3 & 24.9 & 20.7 & 20.6 & 29.8 \\
\hline & $\mathbf{1 5}+$ & $\mathbf{1 5 - 2 4}$ & $\mathbf{2 5 - 4 9}$ & $\mathbf{5 0 - 6 4}$ & $\mathbf{5 5 - 6 4}$ & $\mathbf{1 5 - 6 4}$ \\
\hline 2007 & 19.4 & 38.3 & 18.8 & 10.1 & N/A & 19.4 \\
\hline 2008 & 16.8 & 30.5 & 16.4 & 10.5 & 9.6 & 16.9 \\
\hline 2009 & 19.1 & 35.6 & 18.9 & 12 & 10.1 & 19.2 \\
\hline 2010 & 19.7 & 45.5 & 19.1 & 10.9 & 9.7 & 19.8 \\
\hline $2011(\mathrm{Q} 2)$ & 19.9 & 37.3 & 20.6 & 12.1 & 13.0 & 20.1 \\
\hline
\end{tabular}

Source: MONSTAT (LFS)

Young people are, therefore, increasingly finding themselves either inactive or pushed towards the informal labour market, or else are forced to accept jobs with poorer working conditions. The positive thing in young people having the highest unemployment rate lays in them being the most capable of fitting into the modern requirements and trends of the labour market. Consequently, younger people find it easier to gain employment than older people, and do so more quickly. This explains why their share in the labour supply stock is declining.

One of the reasons that has spurred the reduction of youth unemployment might be an increase in demand for occupations that require education levels III and IV (which take a share in total labour demand of approximately $50 \%$ ). This increase has been recorded mostly in trade, catering and tourism. These are sectors that mainly employ young people. An additional reason can be related to the growth of fixed-term contracts that are more acceptable to younger people.

In order to combat youth unemployment, Montenegro has adopted the National Youth Action Plan (NYAP 2007-2012). This is a document which includes active labour market measures for young jobseekers such as training courses; referral to seasonal jobs for graduates; public work for young people with disabilities; traineeships with wage subsidies for graduates; self-employment schemes for the Roma, Ashkali and Egyptian population; and the 'Job for You' programme in the disadvantaged northern region. In addition, it should be noted that it is difficult to attract young, highlyskilled labour due to the relatively low wage levels in the public sector.

\section{Employment policies and labour market institutions}

\section{Fiscal and tax policy}

From the beginning of 2003, the government has attempted to reduce the cost of labour price by making certain cutbacks in the fiscal burden of wages, thereby struggling to motivate employers to register currently-employed workers or to employ new ones. Also, with a reduction in the overall fiscal burden, the motivation for the employment of workers outside the formal economy is reduced. Therefore, a possible 
change to a less favourable fiscal policy would have a negative impact on business in the country.

Over the last five years, in the field of direct taxation, a proportional tax system has been introduced. The aim of this has been the creation of a simple, transparent and efficient tax system, with one rate set below $10 \%$. The rate of corporate income tax has been $9 \%$ since 2005; while the rate of personal income tax amounted in 2007 to $15 \%$ but was reduced to $12 \%$ in 2009 and further in 2010 to $9 \%$. This was done in order to eliminate incentives for taxpayers to manipulate the figures by transferring income from one tax base to the other, since the rate is the same for personal and corporate income.

According to the Law on Contributions for Obligatory Social Insurance, ${ }^{4}$ employers in Montenegro are obliged to pay taxes and social insurance on behalf of the company as well as on behalf of employees for pensions and disability insurance, health insurance and insurance in the case of unemployment. The basis for the calculation and payment of contributions for unemployment insurance is the wage, or compensation for the labour provided, in accordance with the Law, the Collective Agreement and the Labour Contract.

\section{Table 6 - Taxes and contributions on employment in Montenegro}

\begin{tabular}{|l|c|c|c|}
\hline Taxes and contributions & $\mathbf{2 0 0 8}$ & $\mathbf{2 0 0 9}$ & $\mathbf{2 0 1 0}$ \\
\hline $\begin{array}{l}\text { Personal income tax (flat rate) } \\
\text { tax free income } € 70 \text { per month) }\end{array}$ & $15 \%$ & $12 \%$ & $9 \%$ \\
\hline Contributions (employee) & $\mathbf{1 9} \%$ & $\mathbf{1 7 . 5} \%$ & $\mathbf{2 4} \%$ \\
\hline Pensions and disability insurance & $12 \%$ & $12 \%$ & $15 \%$ \\
\hline Health insurance & $6.5 \%$ & $5 \%$ & $8.5 \%$ \\
\hline Insurance against unemployment & $0.5 \%$ & $0.5 \%$ & $0.5 \%$ \\
\hline Contributions (employer) & $\mathbf{1 5} \%$ & $\mathbf{1 4 . 5} \%$ & $\mathbf{9 . 8} \%$ \\
\hline Pensions and disability insurance & $9 \%$ & $8.5 \%$ & $5.5 \%$ \\
\hline Health insurance & $5.5 \%$ & $5.5 \%$ & $3.8 \%$ \\
\hline Insurance against unemployment & $0.5 \%$ & $0.5 \%$ & $0.5 \%$ \\
\hline Chamber of Commerce contribution & $\mathbf{0 . 3 2} \%$ & $\mathbf{0 . 3 2} \%$ & $\mathbf{0 . 3 2} \%$ \\
\hline Surtax on personal income tax & $\mathbf{1 3 - 1 5 \%}$ & $\mathbf{1 3 - 1 5} \%$ & $\mathbf{1 3 - 1 5 \%}$ \\
\hline
\end{tabular}

Source: Ministry of Finance

The level of taxes and contributions has declined since 2003, when overall taxes and contributions based on wages were at a level of more than $100 \%$. The current position is that overall taxes and contributions stand at $63 \%$ of the net wage; i.e. the 
overall tax burden is between $40 \%$ and $50 \%$ of the gross wage. This makes Montenegro more business-friendly and also removes the barrier due to which most employers in Montenegro reported a minimal wage in order to pay minimal taxes and contributions.

However, the result of the global economic crisis is that the government of Montenegro has decided to increase pensions and health contributions in order to make the social system more sustainable. This might also be an incentive for employees not to declare work. Nevertheless, the expectation is that this increase is temporary and that the level of contributions will continue to decline in the future. On the other hand, personal income tax has remained at the same level (9\%).

The Montenegrin government annually adopts a Decree on Tax Incentives for Hiring Certain Categories of Unemployed People, in order to encourage the employment of people who are considered to be difficult to employ, including people with disabilities, for a duration of one year. This Decree prescribes that employers who hire people with disabilities are exempted from more than $50 \%$ of the fiscal liabilities (i.e. taxes and contributions for mandatory social insurance) relating to the employee's earnings.

The implementation of this Decree between 2006 and 2009 gave positive results. Namely, the number of people defined as hard to employ (those made redundant, the long-term unemployed, etc.) was reduced from about 12000 in 2006 to less than 6000 in 2010. Additionally, a significant number of people were employed through a programme of seasonal and public work during 2009 and 2010.

\section{Education policy}

A high quality education system is very important for individuals and society, since such importance could be visible through providing the possibility for everyone to develop through knowledge, skills and competences. This would enable citizens to learn and have personal development, satisfaction and advancement throughout their life, and would ensure their own participation in the labour market. In addition, it would facilitate employability and the prevention of social exclusion.

The government of Montenegro has recognised the importance of the creation of a knowledge-based society and has adopted different strategic and documents which are in line with the Lisbon Strategy.

The adoption of the Law on National Vocational Qualifications ${ }^{5}$ significantly advances and facilitates the procedure for obtaining vocational qualifications; that is, the crucial skills that are necessary for the labour market and which will have an impact on the planning of human resources and the improvement of the skills structure of the population. Besides this Law, the following are the most important from the aspect of the development of the education system and the labour market in Montenegro:

- General Law on Education 6

- Law on Vocational Education ${ }^{7}$

- Law on Higher Education ${ }^{8}$

5 Official Gazette of the Republic of Montenegro No. 80/08.

6 Official Gazette of the Republic of Montenegro No. 64/02, 31/05 and 49/07.

7 Official Gazette of the Republic of Montenegro No. 64/02 and No. 49/07.

8 Official Gazette of the Republic of Montenegro No. 64/02 and No. 60/03. 
- Law on Adult Education ${ }^{9}$

- Law on Recognition of Educational Qualifications ${ }^{10}$

- Law on Science and Research Activity. ${ }^{11}$

There have been efforts to improve the links between the education system and the needs of the labour market, but it is recognised that much current day knowledge does not fit the modern requirements of the labour market and that the only way of bridging this gap is the promotion of a 'learning society', encompassing adults in the process of lifelong learning. There is no particular strategy for lifelong learning, but the amended Law on Adult Education sets out the principle of lifelong learning as one of its fundamental principles while one of its stated goals is related to an increase in the level of the functional literacy of citizens. Consequently, it is clear that the importance of lifelong learning, and of accepting the idea of the 'learning society', are being recognised. The goals listed in the Law on Adult Education, the Strategy for Adult Education, the Plan for Adult Education and other important documents involve continuous learning and improvement and thereby an acceptance of the concept of lifelong learning.

The Montenegrin authorities adopted a National Employment Strategy for 2007-2010, which is focused on an increase in productivity and work-based skills. This assumes an approach to training the workforce and a tweaking of the education system better to suit the needs of the labour market. A new National Strategy for employment and human resource development for the period after 2011 has been under preparation, while a new 'Strategy for Lifelong Entrepreneurship Learning' as well as a White Paper on the Development of Human Resources in Montenegro up to 2017 have been adopted.

Even so, it seems that there remains a lack of awareness at local level about the importance of linking education and work, which refers to the interdependence of education policy, labour markets and the strategic development of local authorities.

At the same time, a Strategy for Adult Education (2005-2015) has been adopted. Based on this strategy, the Ministry of Education and Science is responsible for preparing a four-year plan for adult education. The Council for Adult Education drew up in March 2010a new four-year Plan for Adult Education, enabling the further development of activities separately for each year and each municipality, and thus the realisation of the activities prescribed by the Strategy for Adult Education and the Plan for Adult Education. The Strategy for Adult Education defined six priority objectives that are similar to the objectives of the other documents and which are related to:

- increasing the level of knowledge and skills of employees in order to achieve faster economic growth

- increasing the level of knowledge and skills of the unemployed in order to move them faster into employment

- increasing the level of social inclusion through adult education

- reaching the values of a democratic society through adult education

- improving environmental protection through adult education

- the use of other forms of education for personal development.

9 Official Gazette of the Republic of Montenegro No. 64/02 and 49/07.

10 Official Gazette of the Republic of Montenegro No. 4/08.

11 Official Gazette of the Republic of Montenegro No. 80/10. 
Regarding institutions at a national level, there is evident co-operation between the institutions of the education system, the EAM and other social partners who are directly connected with the labour market. For instance, the Centre for Vocational Education, in co-operation with the EAM and other institutions related to labour market and education, has identified some areas where there is an increasing demand for occupations (such as in the energy sector) and has established several education programmes supporting energy matters which deliver the level of knowledge applicable to new sources of energy. Additionally, experts from relevant education and labour market institutions have conducted a survey about skill demands in the wood processing, civil engineering and tourism industries. The EAM analyses information regarding training needs in order to design and organise efficient training that is oriented to the labour market. However, there is still a lack of research, especially within adult education, related to educational needs, education supply, the level of functional literacy, the level of development of key competencies and the amount of compliance between education opportunities and labour market needs. Greater effort should be made in order better to match supply and demand, which assumes an effective lifelong learning system and efficient active labour market measures.

One indicator which could provide a clearer picture about the level of focus on goals related to the improvement of the system and the importance of education is that of education spending. ${ }^{12}$ In nominal values, annual public expenditure on education has increased. It amounted to $€ 112 \mathrm{~m}$ in $2007, € 136 \mathrm{~m}$ in $2008, € 139 \mathrm{~m}$ in $2009, € 133 \mathrm{~m}$ in 2010 and $€ 132 \mathrm{~m}$ in 2011.

\section{Table 7 - Annual public expenditure on education (all levels) as \% of total budget expenditures}

\begin{tabular}{|c|c|c|c|c|c|}
\hline $\mathbf{2 0 0 6}$ & $\mathbf{2 0 0 7}$ & $\mathbf{2 0 0 8}$ & $\mathbf{2 0 0 9}$ & $\mathbf{2 0 1 0}$ & $\mathbf{2 0 1 1}$ \\
\hline 12.7 & 14.4 & 9.8 & 9.0 & 9.1 & 9.4 \\
\hline
\end{tabular}

Source: Final Account of Budget Law (2005, 2006, 2007, 2008, 2009, 2010); Law on Budget for 2011.

There has been a constant spending on education in recent years (i.e. as a percentage of total budget expenditures), but the efficiency of that spending unknown since there is no direct relationship between the performance of students and total expenditure.

\section{Active and passive labour market policies}

According to the Law on Employment and Realisation of Rights from Insurance against Unemployment, ${ }^{13}$ active labour market policies (ALMPs) are those plans, programmes and measures which are oriented towards an increase in employment, i.e. the reduction of unemployment. They are defined within the National Strategy for the

12 The Ministry of Finance has added all the extra-budgetary funds into the State Treasury System, based on the Law on Budget (Official Gazette of the Republic of Montenegro No. 40/01, $44 / 01$ and 71/05), since 2008. Therefore, a comparison is not possible between the years before and after 2008. 
Employment and Development of Human Resources, which establishes strategic priorities and goals for employment policy over a period of four years or more.

\section{Recent policies / current situation}

In Montenegro, the EAM is in charge of the implementation of all active employment policies. The National Strategy for Employment and Human Resources Development 2007-2011 defined many measures related to ALMPs. The main goal of the Strategy in that field is the involvement of at least $50 \%$ of long-term unemployed people in active measures in the form of training, re-training, work experience, a job or another employability measure, combined with ongoing assistance with job search. All ALMP measures are aimed at boosting employment and counteracting unemployment, as well as increasing productivity and the quality of work and strengthening social cohesion.

ALMP measures are defined by the Law on Employment and the Realisation of Rights from Insurance against Unemployment, which are as follows:

- providing information on the possibilities for and conditions of employment

- intermediation in employment

- professional orientation

- financing the wages of beneficiaries

- support for self-employment

- subsidies for employment

- education and training of adults

- professional rehabilitation of those who are hard to employ

- public works

- scholarships

- other measures oriented towards the increase of employment opportunities; that is, the reduction of unemployment.

Table 8 - Budget for ALMPs during 2008-2010 (€m)

\begin{tabular}{|l|r|r|r|r|l|}
\hline & $\mathbf{2 0 0 6}$ & $\mathbf{2 0 0 7}$ & $\mathbf{2 0 0 8}$ & $\mathbf{2 0 0 9}$ & $\mathbf{2 0 1 0}$ \\
\hline Active measures & 15.3 & 10.3 & 12.2 & 12.9 & 10.8 \\
\hline Passive measures & 5.5 & 5.7 & 8.9 & 12.6 & 15.2 \\
\hline Total budget & 30.6 & 27.4 & 30.9 & 32.0 & 31.9 \\
\hline
\end{tabular}

The EAM is involved in financing (partly and fully) the employment of beneficiaries. This policy influences an increase in employment opportunities for people who have finished formal education. According to the Law on Employment, the EAM partly refunds costs regarding the contributions of employees if that employer employs people for a certain length of time. This measure has positive effects on the decrease in unemployment.

Public works is a local and national programme for employment which is designed for the opening of new job opportunities and developing the work abilities of unemployed people. Public works are intended to assist people gain labour market attach- 
ment. They can increase their employability if this is combined with training. However, the difficulty facing this measure is its low capacity for labour market integration: workers may become trapped in a spiral of temporary public works programmes.

The EAM conducts programmes for the development of small and medium-sized enterprises and, in this way, has an impact on the increase of employment. The EAM has realised a self-employment programme since 1999, while this was modified in 2008, becoming the Innovated Programme for Self-Employment. Through support for loans, the EAM aims to stimulate the development of SMEs and the additional engagement of the workforce in this area of activity.

With the aim of increasing employment, the EAM has, over the last few years, realised educational activities for unemployed people, part-time employees and employed people for whose occupation there is no market demand, i.e. among men younger than 50 years of age and women younger than 45 . These education programmes include: vocational education, re-education and specialisation. The main advantage of this labour measure is that it works better with broader technical and employability skills that are in demand and where it includes work experience as well as other employment services. However, on the other hand, this measure may produce temporary, rather than sustainable, solutions and, if not well-targeted, may benefit those who are already 'better off'. Training alone may not be sufficient to increase employment prospects.

One ALMP programme that the EAM is continually realising is that relating to seasonal employment. Seasonal employment is mainly oriented towards the tourism sector but, in the recent period, the share of other sectors, such as agriculture, retail, construction, forestry, etc., has increased.

Employment counselling and job-search assistance are more cost-effective means of tackling frictional unemployment. This is due to individuals being provided with information on education and training, trends in the labour market and job opportunities.

Both the National Strategy for Employment and Human Resource Development 2007-2011 and the National Action Plan for Employment for 2010-2011 have defined measures and activities for the restraint of the informal economy. These measures are related to decreasing the costs of doing business, lowering administrative and tax burdens and raising the state's control function in order to eliminate the informal economy.

According to the EAM, the number of unemployed people that have participated in programmes based on active employment measures over the last few years amounts to around $40 \%$ of the total unemployed, which is a relatively high level. However, the results of these measures are not fully known since adequate evaluation data do not exist. At the same time, there needs to be more efficient active measures taken in respect of those who find it particularly hard to find work - chiefly, with regard to the main characteristic of the Montenegrin labour market, the continuing high share of long-term unemployment. According to the Labour Force Survey, this share amounted to $80.3 \%$ in Q2 of 2011. The share of long-term unemployed people being still so high suggests that active labour market measures need to be more successful. The groups most affected are vulnerable ones, such as people with disabilities, women, elderly people, etc., who are the most numerous among the long-term unemployed. 
Despite all the different projects and programmes conducted by the EAM, the programmes were characterised by a low level of participation of people with disabilities - only around $2 \%$ of participants had disabilities during 2009 and 2010 . This indicates that there needs to be more specific active labour market measures that are directly focused on people with disabilities, and that such projects and measures should facilitate a higher rate of their participation.

More active labour market measures are also required in the area of gender equality and which address the position of women on the Montenegrin labour market, since it is obvious that there is still a large amount of inequality between men and women in terms of employment, unemployment and activity. Some projects have been started, however, in the area of enhancing female entrepreneurship. At the end of 2009, the Union of Employers started a project for female entrepreneurs, with a target of thirty planned start-ups.

Furthermore, the public works 'Sunny Workshop' programme was conducted in 2010 by the EAM in co-operation with the social partners. This measure showed positive results, since around seventy people from different municipalities signed an employment contract for a definite period of one month to one year, creating a positive impact on the labour market and in society. However, this is not sufficient, since there is still a huge number of workers with disabilities (almost 2 000) on the path to employment.

The project 'We Are All Equal' was not successful since it did not provide the results anticipated (i.e. it did not have a significant effect on the employment of people with disabilities). Representatives of some local governments were included in these activities, but their continuing participation and involvement is required. This would result in the establishment of a large number of projects with the aim of supporting the employment of people with disabilities.

Currently, there are many programmes and measures related to young unemployed people, since this part of the population is greatly affected by unemployment (especially those with higher education). The Montenegrin government is consequently operating a National Youth Action Plan with reference to the 2007-2012 period. This Plan assumes different active labour market measures and programmes for young unemployed people that are seeking work, such as training courses for different positions and purposes, different public works and seasonal jobs for young people with disabilities, wage subsidies for aspiring job hunters, etc. However, the effects and overall impact of these measures are not known, owing to the lack of evaluation data.

Passive labour market measures are those related to financial compensation for unemployment. Relative to the average wage, unemployment benefit is quite low, ${ }^{14}$ and thus it cannot be treated as an important supporting measure for those who lose their job. According to the EAM, the number of recipients is above 12 000. Primarily, transition processes have created redundancies covering a wide range of unemployed people.

14 The amount of unemployment benefit is set at $65 \%$ of the national basic minimum wage, and currently amounts to $€ 37.50$ (net), plus paid social security contributions. 
According to the new Law on Employment, the period for receiving compensation has been reduced - a change which was introduced so as to narrow the list of recipients. On the other hand, the qualitative restructuring of compensation would lead to the stimulation of employment.

\section{Public employment service (EAM)}

The EAM is legally incorporated with rights, duties and responsibilities that are based within the Constitution of Montenegro, the Law on Employment and the Professional Rehabilitation of People with Disabilities and the Statute of the EAM. The EAM performs a public service which aims to meet needs in the field of employment across the territory of Montenegro. The EAM pursues its own influence on the labour market in Montenegro via implementation of the law and other labour regulations, including concerning health, pensions and the insurance of people with disabilities, etc. The main roles of the EAM are as follows:

- an agency between employers and employees

- prepare people for employment

- research, planning and development

- ensuring insurance rights in the case of unemployment

- offering professional information and guidance, organised in specialised centres called CIPS (which are still not operational in all municipalities)

- compilation of statistics (unemployment and employment; the demand for employees; official certificates; data processing; information and analysis; etc.).

The main role of the EAM is to act as an intermediary in the employment process. This role is performed through:

- monitoring actual and expected needs for certain employee profiles, as well as technical and other labour requirements

- notifying employers of the possibilities for providing necessary employees

- notifying unemployed people and others of the conditions and possibilities for the employment and realisation of other rights based on unemployment

- participation in the creation and delivery of active and passive labour market policy measures

- a management agency for announcing and filling job vacancies, participation in the selection of candidates and preparation for employment.

During previous years, the EAM has launched several projects and programmes regarding the implementation of ALMPs, such as: the financing of internships; public works; encouraging entrepreneurship through loans; preparation for employment; seasonal employment; employment of people with disabilities, etc. The main goal of these projects was the increase of employment, the reduction of unemployment and the improvement of the quality of jobs, with fixed objectives within each priority and the determination of measures for each goal within the active plan on the basis of fixed activities.

Within the ALMPs, the stimulation of employment through the financing of skills improvement programmes for candidates with different levels of education is of great importance. Between 2004 and 2010, more than 10000 candidates were employed. In the same period, the EAM participated in the financing of wages for about 7000 can- 
didates. In addition, regarding seasonal employment, the EAM included via this programme around one-quarter of unemployed people according to evidence from 2009 and 2010. Within programmes that are aimed at the re-adjustment of the labour force and companies to the labour market, training-related programmes and courses that are aimed at the improvement of the skills of potential employees are of great importance. In the period between 2003 and 2010, about 25000 persons attended such programmes.

In the 2003-2010 period, the EAM, in co-operation with the relevant ministries, municipalities, public institutions and NGOs, employed more than 5000 people on public work programmes. These public works, organised in order to aid the implementation of different social, cultural, communal and environmental, etc. programmes, are based on unprofitable but publicly valuable work. These programmes influence the creation of new jobs and improve the potential for work, the level of knowledge and skills, etc.

The EAM has realised a programme of self-employment since 1999, related to the continuing stimulation of employment and entrepreneurship in Montenegro. This programme has provided credits with conditions better than those on the market. In September 2008, the Employment Office started with the realisation of the Innovated Programme for Continuous Employment and Entrepreneurship Stimulation in Montenegro, which represents continuity with the ongoing Programme of Self-Employment. The main goal of the Innovated Programme was to provide loans with special conditions related to the realisation of quality, economically-tenable business ideas. All this with a view to stimulating entrepreneurship development, with special attention paid to less-developed municipalities, and the creation of new, efficient small businesses that would create jobs over a long period.

So far, more than 10000 loans have been approved, with a total value of more than $€ 50 \mathrm{~m}$, and more than 16000 people have been employed through this kind of help.

Regarding the strengthening of its institutional capacities, the EAM plans to establish an efficient monitoring and evaluation system. Also, several bodies have been established to monitor and supervise the implementation of education, training and active labour market policies, such as the Social Council, the Council for the Implementation of the Strategy for Human Resource Development in the Tourism Sector of Montenegro and the Steering Committee of the Employment Agency of Montenegro. This Committee is in charge of suggesting measures for employment and scholarship policy, conducting employment programmes and plans and undertaking other HRD activities. It is constituted on a tripartite basis.

In addition, the IPA 2008 project Labour Market Reform and Workforce Development is aimed at the improvement of the capacity of the Ministry of Labour and Social Welfare and the labour market institutions, as well as the further development of its analytical functions and the evaluation of employment policy for human resources, and within this, of the Ministry's active employment measures. 


\section{Migration trends}

According to MONSTAT data, around 55 000, or about $9 \%$, of Montenegrins live or work abroad. ${ }^{15}$ However, these movements are logical bearing in mind the poor economic conditions and the wars in the region during the nineties. Montenegro also received a large proportion of refugees and internally displaced people resulting from the conflicts in the region. In 2008, there were about 8500 refugees from the Federation of Bosnia and Herzegovina and from Croatia, and 16200 from Kosovo under UNSCR $1244 / 1999$, living in the country. ${ }^{16}$ Also, during recent years, Montenegro has received seasonal migrants from neighbouring countries, such as Serbia, the Former Yugoslav Republic of Macedonia, the Federation of Bosnia and Herzegovina and Kosovo under UNSCR 1244/1999. They are mainly engaged as an additional labour force during the tourist season in sectors such as tourism and construction.

Regarding internal migrations, over the last twenty years these have intensified from the northern part of the country to the capital, Podgorica, and to the southern region. This indicates that almost all eleven northern municipalities have registered a reduction in the number of citizens, while the opposite has occurred in Podgorica and the coastal region. In 2010, the share of the inactive population was highest in the northern part of the country (45.3\%), while in the southern region, and especially in Podgorica, it is significantly lower, at $41 \%$ and $33.7 \%$, respectively. Podgorica is the capital and administrative centre of Montenegro, with a growing number of citizens over the years. The southern region is also developed, with increasing opportunities for quality of life. On the other hand, the northern part of Montenegro is mainly oriented towards the industrial sector (textiles, leather, wood processing, etc.), with many closed factories that have pushed people to migrate to the more service sector-oriented towns in the central and southern regions. With the closure of these enterprises, local workers have been forced to seek a new way of financing their existence. Some of them have gone into agriculture, while a significant number have left the region by migrating to the central and southern parts of the country, thus changing the demographic picture of the country.

All this reveals that the labour market in the north of Montenegro is under-developed and that special attention has to be paid to its development. Due to the poor infrastructure in the north of Montenegro, agricultural activities have delivered only unsatisfactory results. In recent years, additional efforts have been made in order to assist the development of the north.

Around two-thirds of the Montenegrin population currently lives in urban communities and the proportion of the urban population is registering an increasing trend. The situation is worsened by many schools in rural parts of Montenegro closing due to the low number of students. Naturally, these movements have put pressure upon labour markets in urban areas. 
Additionally, the labour force in Montenegro lacks mobility, despite the relatively small distance between towns. ${ }^{17}$ The trend of mobility of the labour force is poor due to the obstacles of geography, the mismatch between wages and living costs and the especially poor working conditions. Poor labour mobility (due to the small size of the country) refers to a situation in which one individual works and lives in the same place, and not to the trend of internal migrations that relates to the movement of one person's permanent residence from his or place of birth, or previous residence, to another. In other words, there are examples of unemployed people in Montenegro that prefer to be unemployed rather than travel to another town for the purposes of a job. However, those who have internally migrated, once they have settled in another place, tend to remain there permanently, or for the long-term.

Nevertheless, during the course of the tourist season, the mobility of the labour force is somewhat higher towards the coastal region which, in turn, leads to increased overall employment.

\section{Conclusions}

By far the greatest problem of unemployment in Montenegro is the structural unemployment seen in the discrepancy between labour supply and demand with regard to certain jobs. There is a hyper-production of human resources in certain fields of work while, on the other hand, there is a lack of interest in the construction industry, agriculture, forestry, wood processing, etc. even though there is a labour market demand for these professions.

The problem of unemployment is additionally augmented by the structure of unemployment. Namely, with a drop in the number of unemployed people, the share of the 'hard to employ' is increasing. All of them are, over a longer period of time, in a poor social position.

The negative effects of the global crisis were noticed on the Montenegrin labour market with some delay in comparison with the rest of the economy. The first signs of such negative trends were recorded at the end of 2009 (i.e. in the last quarter) and during 2010. In 2009, industrial sub-sectors such as the Aluminium Plant (KAP), the Steel Factory and Bauxite Mine Nikšić, as a consequence of restructuring, started to record a decreasing number of employees, and this continued in 2010 . The problems in manufacturing industry need to be resolved by restructuring and supporting the major companies in the sector. Bearing in mind the number of people that are planned to be laidoff in the future, it can be expected that the number of recipients of unemployment benefits will increase.

Evidently, the increase in employment and the reduction of unemployment are the main priorities for the medium-term in Montenegro. This requires that full attention be paid to both demand and supply on the labour market, as well as the provision of assistance for the unemployed to become integrated in the labour market. There is a need to foster labour mobility and make the labour market more flexible by mitigating the geographical constraints, underpinning the development of the infrastructure, cre-

17 LFS data speaks in favour of this finding. In 2010 , over $90 \%$ were working in the same municipality where the household was located. 
ating new programmes and making living and working conditions for the local population much better - all with a view to keeping them from migrating to other parts of the country.

The Montenegrin government and the local authorities should continue fighting against long-term unemployment and youth unemployment, coping with the problem of structural unemployment and matching labour supply to labour demand, tackling the problems caused by the global economic crisis, developing programmes for work with people who are hard to employ, reducing the regional differences in employment and unemployment and preventing poverty in the north of Montenegro.

Montenegro needs further and faster encouraging of the development of SMEs, entrepreneurship and employers to create more jobs. SMEs should be seen as the main driver of new job creation and the reduction of the poverty level. Also, there is a need for the improvement and promotion of female employment, and especially of female entrepreneurship since women need assistance in obtaining loans for business start-ups due to the unsatisfactorily low number of women who are owners of real estate.

In order to resolve the unemployment problem, it is necessary to draw up a longterm strategy concerning the labour market. Measures and activities have been aimed at reducing structural imbalances in the labour market. Numerous active labour market policies (measures) have been designed and implemented during the recent period, but have still not completely achieved the desired results, since their impact on the labour market (in terms of the activation of targeted groups) is still limited. The main reasons for the limited success of these measures can be found in the limited budget for the conduct of such policies.

The links between education and the labour market should be extended i.e. there is a need for an alignment between the supply of education and labour market demand, as well as for increasing the quality of the labour supply. This relationship is a prerequisite for the creation of active employment policies since it often happens that the educational profile of individuals does not match the requirements of the labour market. The field of education and the labour market needs to be included in an adequate manner. The idea of introducing lifelong learning into the education system has also had a significant impact on the labour market. It is more difficult to create a policy that should overcome this 'problem' in new action plans.

Finally, continuing work is also required as regards the elimination of all discriminatory provisions relating to the labour market, as recommended by the European Partnership and the Stabilisation and Accession Agreement, especially since vulnerable groups face specific difficulties when entering the labour market and, therefore, require special attention.

\section{References}

Employment Agency of Montenegro Annual Reports.

Employment Agency of Montenegro Labour Market Reform and Workforce Development, working material (IPA funded project).

European Commission (2008) Social Protection and Social Inclusion in Montenegro. 
European Commission (2010) Assessment of Labour Market in Montenegro.

General Collective Agreement

General Law on Education Official Gazette of the Republic of Montenegro 64/02, 31/05 and $49 / 07$.

Government of Montenegro Decree on Tax Incentives for Hiring Certain Categories of Unemployed Persons

Government of Montenegro National Youth Action Plan (NYAP 2007-2012).

Government of Montenegro National Employment Strategy 2007-2010.

Government of Montenegro Strategy for Adult Education (2005-2015).

Government of Montenegro Strategy for Life-Long Entrepreneurship Learning.

Government of Montenegro The White Book - Human Resources Development in Montenegro until 2017.

Institute for Strategic Studies and Prognoses (2006) Labour market institutions in Montenegro.

Institute for Strategic Studies and Prognoses (2007) Labour Force Survey.

Law on Adult Education Official Gazette of Republic of Montenegro 64/02 and 49/07.

Law on Budget (2005-2011).

Law on Contributions for Obligatory Social Insurance Official Gazette of Republic of Montenegro No. 13/07.

Law on Employment and Realization of Rights from Insurance against Unemployment Official Gazette of Republic of Montenegro No. 14/10.

Law on Employment and Work of Foreigners Official Gazette of Republic of Montenegro No. 04/11.

Law on Gender Equality Official Gazette of Republic of Montenegro No. 46/07.

Law on Higher Education Official Gazette of Republic of Montenegro No. 64/02, No. 60/03.

Law on National Vocational Qualifications Official Gazette of Republic of Montenegro No. 80/08.

Law on Professional Rehabilitation and Employment of Disabled Persons Official Gazette of Republic of Montenegro No. 50/08.

Law on Recognition of Education Qualifications Official Gazette of Republic of Montenegro No. 4/08.

Law on Science and Research Activity Official Gazette of Republic of Montenegro No. $80 / 10$.

Law on Social Council Official Gazette of Republic of Montenegro No. 16/07. 
Law on Vocational Education Official Gazette of Republic of Montenegro No. 64/02, No. 49/07.

MONSTAT (2006-2011) Labour Force Survey. 